\title{
The Integration of Remote Sensing and Field Surveys to Detect Ecologically Damaged Areas for Restoration in South Korea
}

\author{
Kyungil Lee ${ }^{1}$, Hyun Chan Sung ${ }^{1}$, Joung-Young Seo ${ }^{2}$, Youngjae Yoo ${ }^{1}$, Yoonji Kim ${ }^{1}$, \\ Jung Hyun Kook ${ }^{3}$ and Seong Woo Jeon $1, * \mathbb{D}$ \\ 1 Division of Environmental Science \& Ecological Engineering, Korea University, 02841145 Anam-ro, \\ Seongbuk-gu, Seoul 02841, Korea; leedake@korea.ac.kr (K.L.); wona2015@naver.com (H.C.S.); \\ lemonesty@korea.ac.kr (Y.Y.); yoonjik605@korea.ac.kr (Y.K.) \\ 2 DNC Engineering, 69, Songdam 2-ro, Anjung-eup, Pyeongtaek-si 17941, Korea; dnceng@naver.com \\ 3 Eco, Environment, Education, 583, Yangcheon-ro, Gangseo-gu, Seoul 07547, Korea; jhkook@ethree.co.kr \\ * Correspondence: eepps_korea@korea.ac.kr; Tel.: +82-02-3290-3043
}

Received: 15 October 2020; Accepted: 9 November 2020; Published: 10 November 2020

\begin{abstract}
Ecological damage refers to the reduction in the value of the environment due to human activities such as development. The intensity of ecosystem damage is worsening worldwide. Although the importance of restoration projects to reduce ecosystem damage is increasing, they are difficult to carry out, owing to the absence of data and monitoring of damaged areas. In this study, ecologically damaged areas for restoration in South Korea were detected using remote sensing and field surveys. For the analysis, national standardized vector datasets and Google Earth images were used; field surveys were conducted from 2018 to early 2020. Our results showed that $62 \%$ of the ecological damage that occurred in South Korea existed in forest ecosystems; the damaged areas were mostly smaller than $50,000 \mathrm{~m}^{2}$. Additionally, most of the causes and types of damage due to human activities such as development were soil erosion related. The results also suggest the importance of obtaining monitoring data on ecologically damaged areas and the importance of establishing an appropriate restoration plan using this data.
\end{abstract}

Keywords: ecological degradation; restoration; remote sensing; field survey

\section{Introduction}

Ecological damage is the reduction in the value of the environment to meet socio-economic needs, including land degradation, deforestation, and land pollution. Ecological damage can be caused by human anthropogenic activities or natural phenomena [1,2]. As per the Millennium Ecosystem Assessment, approximately $60 \%$ of the world's ecosystems have been damaged through human use; the damage caused by land degradation is estimated to cost US\$4.3-20.2 trillion per year worldwide [3]. Furthermore, additional damage may occur owing to the negative impacts on biodiversity, human health, and food security in these damaged areas [4]. To prevent this damage, the goal of the ecological restoration of more than $15 \%$ of the world's damaged ecosystems has been set through the Convention on Biological Diversity; related research is also increasing [5-9].

As per existing research cases, the damage caused by urbanization and the social demand for ecosystem restoration are increasing, as is the importance of information about damaged areas and the policy role for restoration projects.

However, in the absence of restoration-related monitoring data, difficulties in policy decisions such as restoration site prioritization and restoration planning are presented [5,6,8,9]. Monitoring is recognized as a costly and time-consuming operation; thus, it is often not performed before and after a 
restoration project. However, if monitoring is not performed, the evaluation of damage and restoration recovery trajectories becomes impossible [10,11]. Additionally, for restoration site prioritization and planning - a limitation of current restoration projects - the location, size, and type of the damaged area must be identified in advance through monitoring: a restoration direction that considers that these aspects should be established. If the restoration project is executed sporadically owing to a lack of planning, an inefficient use of budget and manpower due to restoration project may occur, and the ecological connectivity of the restoration area may be insufficient [7].

The role of remote sensing in restoration planning and monitoring has increased, especially in the last decade, owing to improved sensor technology and data availability [12]. Its main advantages include its capabilities to provide complete information on land cover as well as analyze that information [13]. Remote sensing tools such as land-use and land-cover (LULC) data have been used to track land-cover change around protected areas [14-18]. Additionally, national standardized vector datasets have been developed for country-wide comparisons of land cover based on remotely sensed data, such as the National Land Cover Dataset by the US Geological Survey (USGS) [19]. However, most studies using remote sensing only have a limited study area such as protected area; there have been limitations that could not be overcome except by carrying out field surveys for the verification of the area where the change occurred and there is no basis for judging whether it was an illegal damage or a just natural change.

To establish a restoration direction and plan for the damaged area, it is necessary to collect information such as the cause, type, and extent of the damage and construct a dataset that can be used by the restoration-related ministries for each type [7,14]. In addition, the dataset for damaged areas is important for the environmental offsets policy, which is increasingly popular in conservation worldwide. Environmental offsets mean 'the measurable conservation outcomes resulting from actions designed to compensate for significant environmental impacts arising from development project despite appropriate prevention measures [20,21]. Restoration is one of the offset methods that allows for an easier measurement of loss versus gain compared to other methods and provides a unique opportunity to maintain spatial ecological connectivity. However, restoration can be complicated by logistical, social, and political constraints and requires early planning to ensure adequate baseline information to inform feasible restoration goals and practice [22]. Therefore, it is important to construct spatial information and a criterion of illegally damaged areas for legitimate restoration project plans and to advance field trials to provide aid in an assessment of feasibility. The technique of damaged area monitoring using both remote sensing and field survey would increase the data quality compared to a simple remote sensing monitoring, whilst reducing the cost compared to a simple filed survey for a specific region [23].

In this study, we aimed to introduce a two-step methodology to detect ecologically damaged areas and monitor them using both remote sensing and field surveys to build a damaged area database for legitimate restoration planning. We first used remote sensing data such as national standardized vector datasets and Google Earth data to analyze the illegally changed natural environment areas and then conducted field surveys to verify the derived results and determine the type of damage.

\section{Materials and Methods}

\subsection{Study Area}

The study area included the inland areas of South Korea: approximately $99,827 \mathrm{~km}^{2}$ (latitude $34^{\circ} \mathrm{N}-38.5^{\circ} \mathrm{N} \&$ longitude $126^{\circ} \mathrm{E}-129.5^{\circ} \mathrm{E}$ ) divided into 16 regional local governments (Figure 1$)$. The dominant land-cover categories of the study area are forest (67.7\%), agricultural land (22.2\%), urban areas (4.6\%), and others, including grassland, water, barren land, and wetlands (5.5\%) [24]. South Korea experiences damage to the natural environment in various forms and magnitudes owing to natural disasters such as flood due to rainfall, soil erosion due to wind and gravity, as well as human activities such as land development and road construction [7]. Additionally, socio-economic 
damage is also increasing owing to the deterioration of ecological health, disconnection with adjacent ecosystems, and inhibition of natural landscapes in the damaged area. However, since the locations of and information about the damaged areas are not known in advance, specific policies or prior plans are not established, and sporadic restoration projects are being carried out by government departments [7]. Figure 1 is the general land cover status of South Korea provided by the Ministry of Environment (MOE) [25].

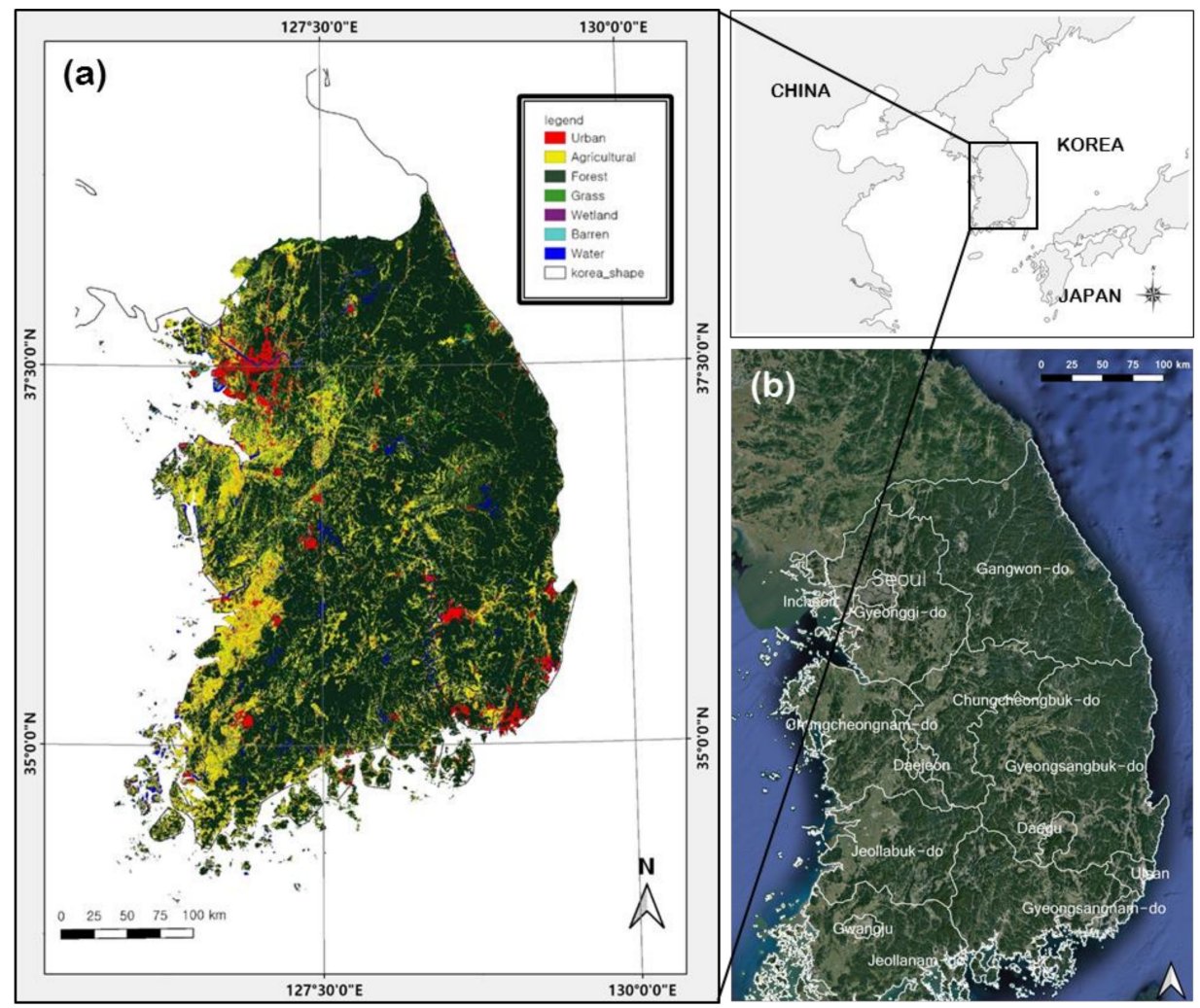

Figure 1. (a) The study area and the land cover status; (b) a satellite image of the study area showing the 16 regional local governments.

\subsection{Materials}

\subsubsection{Land-Cover Data}

To analyze the land-cover changes (LCC) in the study areas, the level 2 land-cover maps of 2004 and 2013 produced by the MOE of South Korea were used [25]. The level 2 land-cover maps were constructed using satellite images such as Indian Remote Sensing (IRS-1D), IKONOS imageries, and aviation images at a 5-m spatial resolution. First, land cover classification was performed twice using $5 \mathrm{~m}$ resolution images and the constructed map was examined and supplemented through fieldwork; the criteria for classification accuracy should be at least $95 \%$ on average (a detailed explanation of the processing chain and validation methods used can be found at the Environmental Geographic Information Service in Korean) [25]. These remote sensing-based maps have been used by the scientific community for various purposes; however, it appears that limited research has been conducted to locate and quantify ecologically damaged areas using these maps.

The level 2 land-cover map classified the entire land into 22 land-cover types. To derive the ecologically damaged areas, the data from 22 categories of land cover were reclassified as "forest," "grass," "wetland," "agricultural area," and "barren area" according to this study's purpose (Table 1). Most related studies used land-cover maps constructed using 30-m resolution satellite images; however, here, we used 5-m resolution land-cover maps, so that more accurate and detailed LCC could be identified. 
Table 1. Two-level hierarchy of land-cover categories in the 2004 and 2013 land-cover maps provided by the South Korean Ministry of Environment ("Original classification") and the reclassified categories used in this study ("Classification for this study").

\begin{tabular}{|c|c|c|}
\hline \multicolumn{2}{|c|}{ Original Classification } & \multirow{2}{*}{ Classification for This Study } \\
\hline Level 1 & Level 2 & \\
\hline \multirow{6}{*}{ Urban Area } & Residential Area & \multirow{6}{*}{ Developed Area } \\
\hline & Industrial Area & \\
\hline & Commercial Area & \\
\hline & Cultural, Sport, recreational Area & \\
\hline & Traffic Area & \\
\hline & Public Facilities & \\
\hline \multirow{5}{*}{ Agricultural Land } & Rice Paddy & \multirow{12}{*}{$\begin{array}{l}\text { Natural and Semi-Natural } \\
\text { Environment Area }\end{array}$} \\
\hline & Field & \\
\hline & Cultivation under Structure & \\
\hline & Orchard & \\
\hline & Other Cultivation & \\
\hline \multirow{3}{*}{ Forest } & Broadleaf Forest & \\
\hline & Coniferous Forest & \\
\hline & Mixed Forest & \\
\hline \multirow{2}{*}{ Grass } & Natural Grass & \\
\hline & Artificial Grass & \\
\hline \multirow{2}{*}{ Wetland } & Inland Wetland & \\
\hline & Coastal Wetland & \\
\hline \multirow{2}{*}{ Barren } & Natural Barren & \multirow{2}{*}{ Potentially Damaged Area } \\
\hline & Artificial Barren & \\
\hline \multirow{2}{*}{ Water } & Inland Water & \multirow{2}{*}{ Water } \\
\hline & Seawater & \\
\hline
\end{tabular}

\subsubsection{Land-Use Data}

Change detection using LCC analysis allows scientists to look at changes in land use or land cover and disturbance using binary comparisons contrasting conditions between two discrete time periods $[19,26]$. However, to determine whether the land was illegally damaged, additional analysis is needed in an area where LCC occurred. The land-use zoning map was used for this analysis in this study.

Land-use zoning is one of the most effective measures to control various land-use activities. It first originated for the re-construction of disordered and undisciplined cities and later attracted substantial attention worldwide $[27,28]$. Some countries, like the United States, have employed municipal/country zoning ordinances to optimize residential, industrial, commercial, and ecological land use in rural and urban planning, but China introduced regional land-use zoning to resolve land-use conflicts between rural and urban development and keep agricultural land from the occupation of urban expansion [29-31]. In South Korea, the land-use zoning system was introduced for the same purpose as that in the United States; it is divided into four areas: urban areas, control areas, agricultural and forest areas, and natural environment conservation areas (Ministry of Land, Infrastructure and Transport [32] (Table 2). 
Table 2. Division of land-use zoning in South Korea defined by South Korean Ministry of Land, Infrastructure and Transport.

\begin{tabular}{cc}
\hline Division & Description \\
\hline Urban areas & $\begin{array}{c}\text { Areas requiring systematic development, maintenance, management, } \\
\text { preservation, etc., where the population and industries are concentrated, or } \\
\text { such concentration is anticipated therein }\end{array}$ \\
\hline Control areas & $\begin{array}{c}\text { Areas to be systematically controlled corresponding to urban areas to } \\
\text { accommodate the population and industries of urban areas or those } \\
\text { requiring control corresponding to an agricultural and forest area or natural } \\
\text { environment conservation area to promote the agricultural and forest } \\
\text { industry and preserve the natural environment or forests }\end{array}$ \\
Agricultural and forest areas & $\begin{array}{c}\text { Areas necessary to promote the agricultural and forest industry and } \\
\text { preserve forests, such as agricultural promotion areas under the Farmland } \\
\text { Act or conserved mountainous districts under the Mountainous Districts } \\
\text { Management Act that do not belong to urban areas }\end{array}$ \\
\hline Natural environment conservation areas & $\begin{array}{c}\text { Areas necessary to preserve the natural environment, water resources, } \\
\text { coastal areas, ecosystems, water supply resources, and cultural heritage } \\
\text { assets and protect and foster fishery resources, etc. }\end{array}$ \\
\hline
\end{tabular}

Land-use zoning for sustainable development includes a set of sustainability objectives related to urban sprawl restriction and ecological environment restoration; each land-use zone type has been used to regulate land-use activities at the regional local government scale in South Korea, which is the major urban management scale [28,32]. Therefore, the land-use zoning map can be used as the basis for judging illegally damaged areas among the changed areas; this study utilized the land-use zoning map for 2018 provided by the National Spatial Data Infrastructure Portal (NSDI) [33].

\subsubsection{The Area Subject to Environmental Impact Assessment Data (EIA Map)}

The Environmental Impact Assessment (EIA) introduced by the United States in the late 1960s and early 1970s has been adopted widely in the rest of the world [34]. In South Korea, the EIA refers to an assessment conducted by surveying, forecasting, and assessing the appropriateness of a site location and the environmental impact of a development project to provide measures for environmental conservation (MOE, 2018). The EIA process has important purposes such as supporting decision making to prevent projects with undesirable environmental impacts and assisting in informing development decisions by instructing a consideration of alternatives (such as locations, scales, and conditions) [34]. The EIA and remote sensing have been used to address environmental problems, but few studies have linked the two fields [35-37]. In the case of studies that combined the two fields, most studies presented the potential of RS data such as satellite imagery to support the EIA; conversely, studies using EIA data to support decision making for RS were rare. The area subject to EIA is under review for development at the national level and can be the basis for judging the area where the land-cover change occurred legally.

In South Korea, information related to the EIA needs to be collected and disseminated through the Information Support System for Environmental Impact Assessment (EIASS) in point of law [38]. In this study, the spatial data of EIA projects conducted until 2018 were acquired through the EIASS and used in the exclusion analysis for the regions derived above [39]. All data used for damaged area detection were projected to the common Projected Coordinate System 'WGS 1984 UTM Zone (EPSG:2097), the same as the Google Earth data (Figure 2).

\subsubsection{Google Earth Data}

In this study, land-cover data from 2004 and 2013 were used, owing to the necessity of using the high-resolution land-cover map constructed for the entire country; at this time, the land-cover condition of the damaged area may differ from that of the present. To modify the differences due to time intervals, we used Google Earth data as the reference data. Google Earth is the most popular virtual 
globe software; it visualizes images as a global mosaic of the Earth using mid and high-resolution satellite and aerial imagery from multiple providers ranging from SPOT5 and Landsat up to aerial orthophotos [40]. The advantages of using Google Earth data are that they have a high resolution $(65 \times 65 \mathrm{~cm})$, available for free, and describe the imagery date [41]. Google Earth's high-resolution data have been used as reference data in many studies; previous research proved the horizontal and vertical precision of these images, and images from 2018 were selected for this study [40-42].
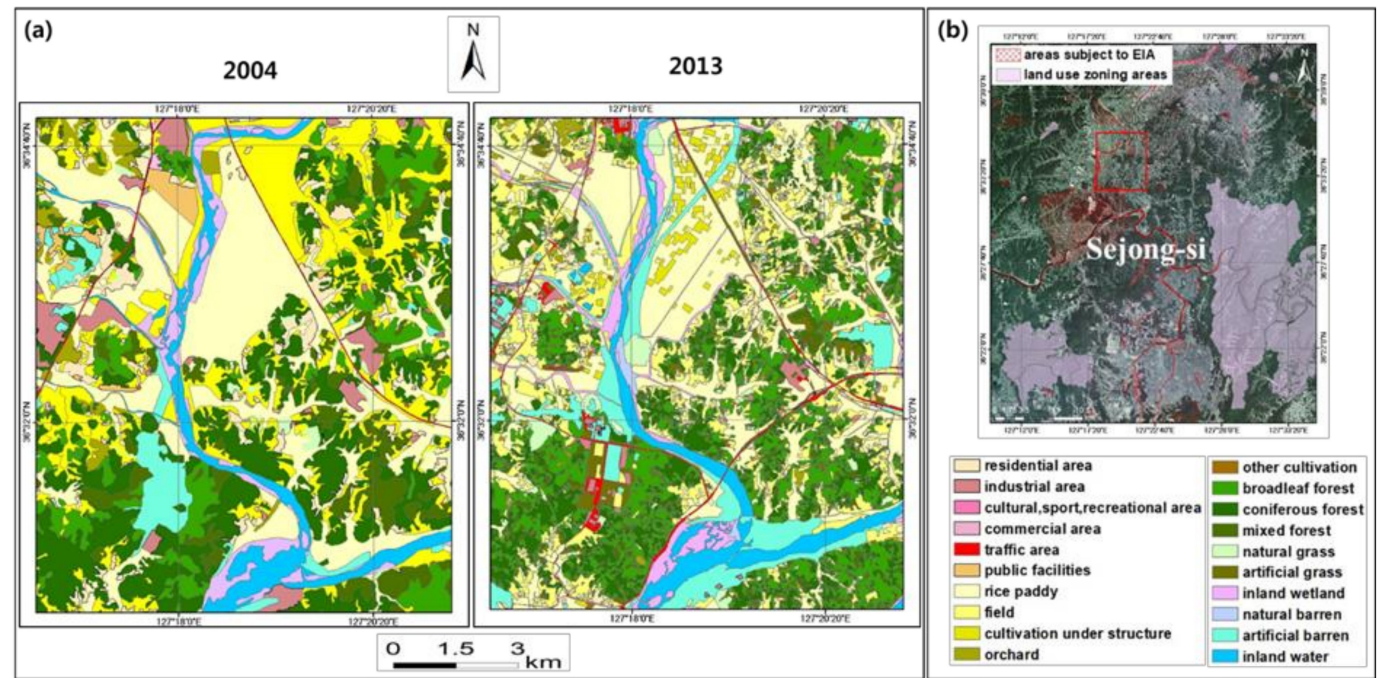

Figure 2. Examples of data used for damaged area detection in Sejong-si in South Korea. (a) Level 2 land cover in 2004 and 2013; (b) examples of areas subject to Environmental Impact Assessment (EIA) and land-use zoning areas (natural environment conservation areas) overlaid on Google Earth imagery.

\subsection{Methods}

\subsubsection{Land-Cover Change Analysis}

In South Korea, the legal definition of environmental damage includes conditions that inflict serious damage on intrinsic functions of the natural environment, for example, overhunting or over gathering wild animals or plants, destroying their habitats, disturbing the order of the ecosystem, impairing the natural scenery, washing away the topsoil, etc. [43]. In this study, the damaged area was defined as the area changed from a natural and seminatural environment area (agricultural land, forest, grassland, wetland) to a potentially damaged area (barren area) according to the legal definition. The areas categorized as natural environment area and potentially damaged area in the 2004 and 2013 Level 2 land-cover maps were used to calculate this.

Change detection has historically been used to look at changes in land cover using binary comparisons, contrasting conditions during two discrete time periods [19]. The over-lay procedure was used to obtain the changes in land cover during the specified time period. A two-way cross-matrix obtained by the procedure was used to describe the change in land-cover area in South Korea by each regional local government. Among the areas where changes occurred, areas that were changed from natural and semi-natural environment areas to potential damaged areas were extracted. Next, among the extracted areas, areas with less than $5000 \mathrm{~m}^{2}$ were excluded because $5000 \mathrm{~m}^{2}$ is the minimum area of the project subject to EIA in South Korea [44].

\subsubsection{Analysis of Illegal Damaged Area}

For areas derived through land cover change analysis, we conducted an overlap analysis using Land use zoning map and EIA map to classify that areas into the illegal and legal changes.

First, when the changed area belonged to urban areas and agricultural and forest areas through overlapping with the land use zoning map, the land cover was intentionally changed for development 
and agriculture purposes. Areas intentionally changed were not illegally damaged and excluded from the list of extracted areas. Contrastingly, if the land cover changed area is on control areas and natural environment conservation areas, there is a possibility that it has been illegally damaged because it is designated to protect the natural environment by the law [32]. The areas belonging to the two zones were not excluded and analyzed by overlapping with the EIA map to determine whether they were illegally damaged. If the area overlaps with the EIA map, development is in progress or can be developed in the future. Therefore, it was excluded from the list of damaged sites and modifications using google earth data were performed on the rest of the areas.

\subsubsection{Modification Using Google Earth Data}

The recent Google Earth data from 2018 were used to determine whether the extracted areas were damaged for real or not and to calculate the exact size of damaged area. Because of the necessity of using the high-resolution land cover map constructed for the entire country there may be a difference according to the time interval even if actual damage occurred at the area before.

First, we checked the current land cover of the polygon of the sites extracted as a damaged area and surrounding of environment. If the target site has already been developed or is difficult to see as a damaged area compared to the surrounding environment, it was excluded from the field survey target area (Figure 3a). Second, if it is judged to be a damaged area, but the polygon of damaged area does not match the with actual area, the polygon of the extracted area was modified to derive an accurate area (Figure 3b). Spatial overlay analysis to derive damaged areas and modification using Google Earth Data were performed using ArcGIS software 10.3 and a field survey was conducted on the list of damaged areas finally derived through modification.
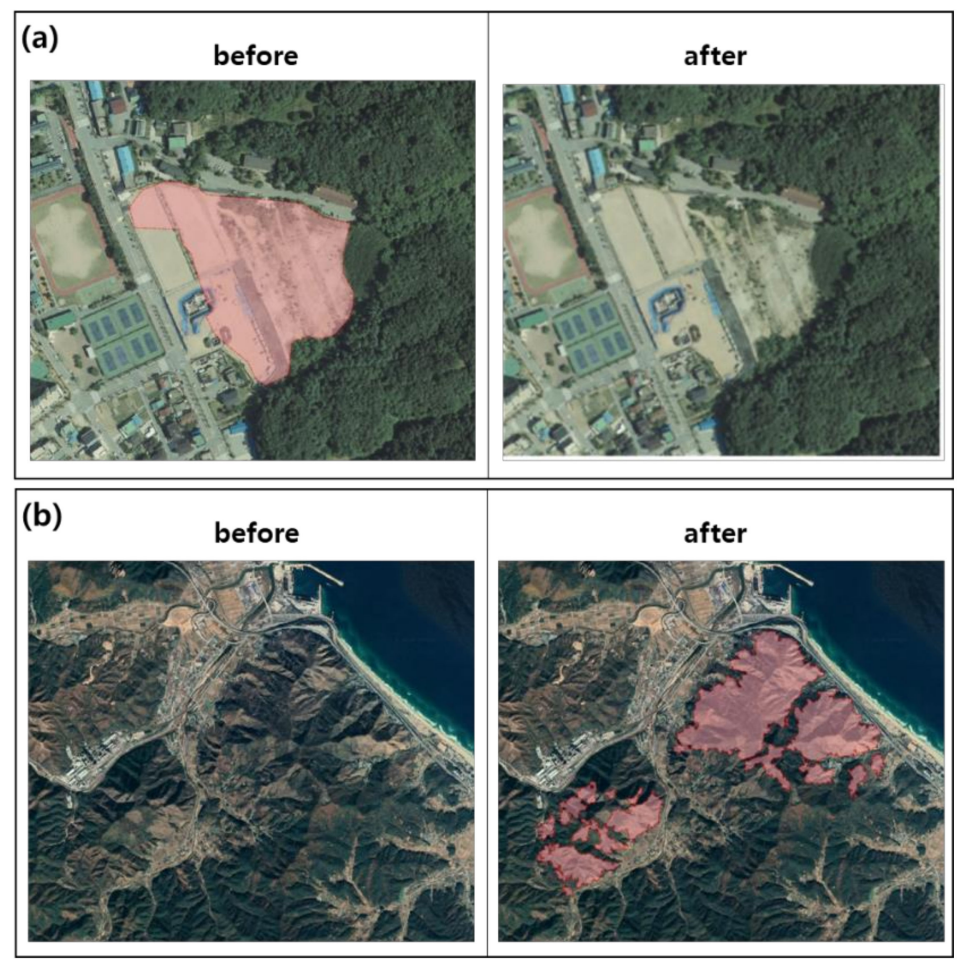

Figure 3. Examples of polygon modification: (a) excluding the developing areas; (b) modifying the area damaged by forest fire for accurate area calculation.

\subsubsection{Field Survey}

From 2018 to early 2020, field surveys were conducted for all the damaged areas detected through remote sensing to verify the identity of the damaged areas and the type of damage. To restore the ecosystem structure in the area where damage has occurred, the cause and status of the damage should 
be identified to establish the restoration direction and plan [7]. During field surveys, we collected the information about the areas that were damaged such as coordinates of the location, surrounding vegetation, damage type, range, cause, etc.

The causes of damage can be divided into natural damage and anthropogenic damage; the types of damage are classified according to the ecological structure of the target site [7]. In this study, the criteria for type of damage based on MOE [7] and Victoria Resources Online (VRO) were used in the field survey [45] (Table 3). The identification of damage occurrence, cause of damage for each area were determined based on investigations involving comparison with the surrounding environment, and the type of damage was determined through expert judgment based on the criteria. The steps from data construction to field survey for ecologically damaged areas detection are shown in Figure 4. Additionally, the land cover-accounting for more than $75 \%$ of the damaged area-was judged as the main ecosystem of the area.

Table 3. Field survey criteria for damage classification.

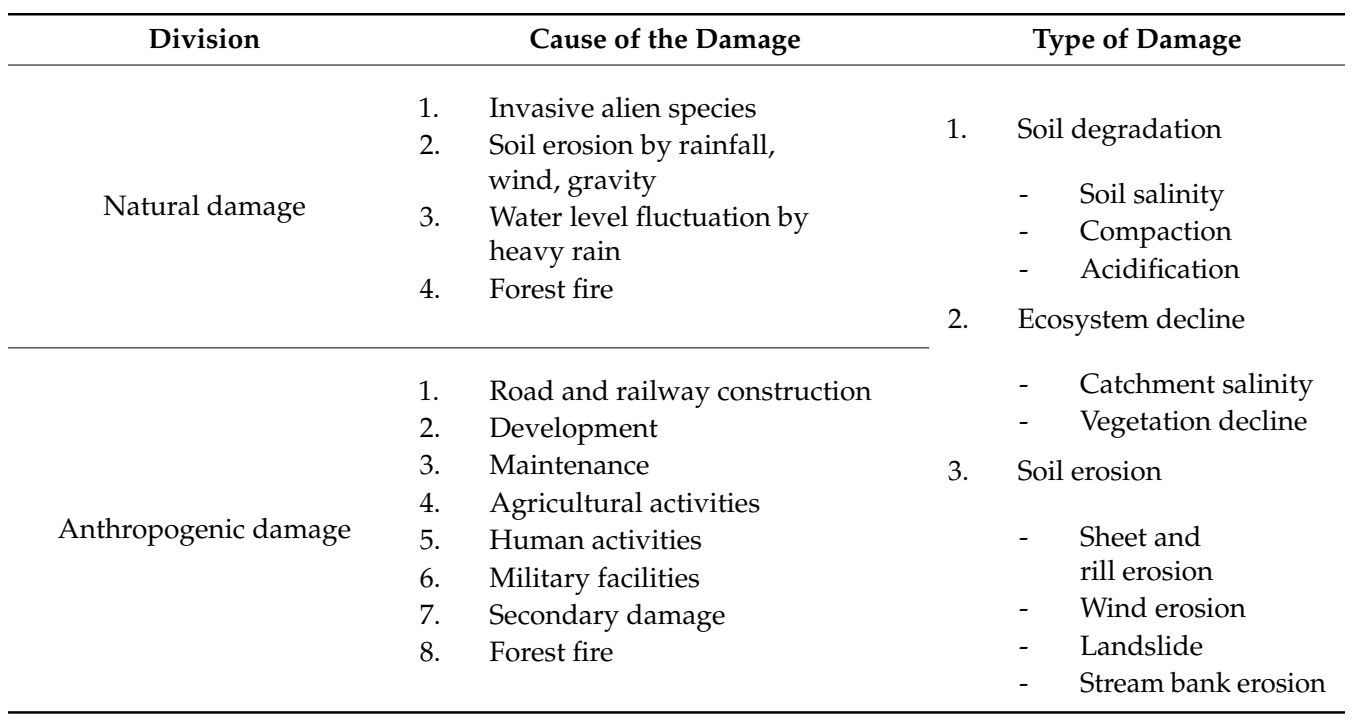

\section{DATA COLLECTION}

Land cover map

- 2 years $(2004,2013)$

$\cdot 22$ categories $\rightarrow 4$ categories

- For land cover change analysis

Land use zoning map

$\cdot 2018$ data

- 4 categories

- For judgement of illegally

damaged area

EIA map

- 2018 data

- 4 categories

- For excluding areas subject to

environmental impact assessment

\section{Google Earth Data}

- 2018 data

- For modification to suit the present

situation

\section{DAMAGED AREA DETECTION}

Land cover change analysis

- Spatial overlay analysis between two land cover maps $(2004,2013)$

- Natural environment area $\rightarrow$ potential damaged area

- Excluding areas less than $5,000 \mathrm{~m}^{2}$

Analysis of defining illegal

damaged area

- Excluding areas belonging to urban areas and agricultural and forest areas in land use zoning map

- Excluding areas overlapped with EIA map

Modification

- To determine weather the extracted areas were

damaged in real or not

- To calculate the exact size of damaged area
FIELD SURVEY

- From 2018 to early 2020

- For the verification of the damaged area and type of damage

- Cause of damage : natural \& artificial

- Type of damage : soil degradation,

ecosystem decline, soil erosion

Figure 4. Utilization data and analysis flow chart for detecting ecological damaged areas. 


\section{Results}

\subsection{Damaged Area Detection}

In total, 399 damaged areas over $5000 \mathrm{~m}^{2}$ were detected using remote sensing in South Korea (Table 4) (Figure 5). Most areas where there was slight damage, such as Seoul, Busan, and Incheon, were promoted to metropolitan cities before and after the 1980s, and urbanization and development took place before other regions. Additionally, the number of development projects that have occurred in the last 10 years (2008-2017) is small compared to the other regions; thus, it is expected that there will be a lower possibility of anthropogenic damage [46] (see Table A1). There were more damaged areas in Gyeonggi-do (84 cases) and Gangwon-do (82 cases) than in the other regions. Gyeonggi-do is the region with the largest number and area of total development projects, including housing site development businesses, according to the metropolitan plan, and is considered to be the region with the highest possibility of anthropogenic damage. In the case of Gangwon-do, the ratio of forest area to total area is $81.5 \%$, the highest in Korea; the average slope of the mountainous areas is also high. Thus, here, naturally occurring landslides and the anthropogenic deterioration of forests are expected to occur more frequently than in other regions [47].

Table 4. Distribution status of damaged areas in South Korea derived through remote sensing.

\begin{tabular}{|c|c|c|c|c|c|c|c|c|c|}
\hline Division & $\begin{array}{c}5000- \\
10,000 \\
\mathrm{~m} 2\end{array}$ & $\begin{array}{c}10,000- \\
50,000 \\
\mathrm{~m} 2\end{array}$ & $\begin{array}{c}50,000- \\
100,000 \\
\mathrm{~m} 2\end{array}$ & $\begin{array}{c}100,000- \\
150,000 \\
\text { m2 }\end{array}$ & $\begin{array}{c}150,000- \\
200,000 \\
\mathrm{~m} 2\end{array}$ & $\begin{array}{c}200,000- \\
250,000 \\
\mathrm{~m} 2\end{array}$ & $\begin{array}{c}250,000- \\
300,000 \\
\mathrm{~m} 2\end{array}$ & $\begin{array}{c}300,000 \\
\mathrm{~m} 2 \sim\end{array}$ & $\begin{array}{c}\text { Total } \\
\text { (Row) }\end{array}$ \\
\hline Seoul * & 2 & 1 & 1 & 0 & 0 & 0 & 0 & 0 & $4(2 \%)$ \\
\hline Busan * & 1 & 1 & 0 & 0 & 0 & 0 & 0 & 0 & $2(1 \%)$ \\
\hline Daegu * & 0 & 0 & 0 & 0 & 0 & 0 & 0 & 0 & $0(0 \%)$ \\
\hline Incheon * & 0 & 0 & 0 & 0 & 0 & 0 & 0 & 0 & $0(0 \%)$ \\
\hline Gwangju* & 1 & 0 & 0 & 0 & 0 & 0 & 0 & 0 & $1(1 \%)$ \\
\hline Daejeon * & 0 & 0 & 0 & 0 & 0 & 0 & 0 & 0 & $0(0 \%)$ \\
\hline Ulsan * & 1 & 1 & 0 & 0 & 0 & 0 & 0 & 0 & $2(1 \%)$ \\
\hline Sejong * & 0 & 0 & 0 & 0 & 0 & 0 & 0 & 0 & $0(0 \%)$ \\
\hline Gyeonggi-do & 20 & 53 & 4 & 0 & 2 & 1 & 3 & 0 & $\begin{array}{c}84 \\
(21 \%)\end{array}$ \\
\hline Gangwon-do & 25 & 44 & 5 & 4 & 0 & 1 & 0 & 3 & $\begin{array}{c}82 \\
(20 \%)\end{array}$ \\
\hline $\begin{array}{l}\text { Chungcheong } \\
\text { buk-do }\end{array}$ & 20 & 29 & 3 & 0 & 0 & 0 & 0 & 0 & $\begin{array}{c}52 \\
(13 \%)\end{array}$ \\
\hline $\begin{array}{l}\text { Chungcheong } \\
\text { nam-do }\end{array}$ & 10 & 14 & 1 & 1 & 0 & 0 & 0 & 0 & $\begin{array}{c}26 \\
(6 \%)\end{array}$ \\
\hline $\begin{array}{l}\text { Jeolla } \\
\text { buk-do }\end{array}$ & 10 & 10 & 1 & 0 & 0 & 1 & 1 & 0 & $\begin{array}{c}23 \\
(5 \%)\end{array}$ \\
\hline $\begin{array}{c}\text { Jeolla } \\
\text { nam-do }\end{array}$ & 17 & 20 & 6 & 1 & 0 & 0 & 0 & 0 & $\begin{array}{c}44 \\
(11 \%)\end{array}$ \\
\hline $\begin{array}{l}\text { Gyeongsang } \\
\text { buk-do }\end{array}$ & 9 & 20 & 3 & 2 & 0 & 0 & 0 & 0 & $\begin{array}{c}34 \\
(8 \%)\end{array}$ \\
\hline $\begin{array}{c}\text { Gyeongsang } \\
\text { nam-do }\end{array}$ & 17 & 21 & 2 & 3 & 0 & 0 & 0 & 2 & $\begin{array}{c}45 \\
(11 \%)\end{array}$ \\
\hline Total (column) & $\begin{array}{c}133 \\
(33 \%)\end{array}$ & $\begin{array}{c}215 \\
(54 \%)\end{array}$ & $\begin{array}{c}26 \\
(6 \%)\end{array}$ & $\begin{array}{c}11 \\
(3 \%)\end{array}$ & $\begin{array}{c}2 \\
(1 \%)\end{array}$ & $\begin{array}{c}3 \\
(1 \%)\end{array}$ & $\begin{array}{c}4 \\
(1 \%)\end{array}$ & $\begin{array}{c}5 \\
(1 \%)\end{array}$ & $\begin{array}{c}399 \\
(100 \%)\end{array}$ \\
\hline
\end{tabular}

*: metropolitan city in South Korea.

Considering the size of the damaged areas, approximately $54 \%$ of the damaged areas was identified with $10,000 \mathrm{~m}^{2}-50,000 \mathrm{~m}^{2}$; this is more than half of the total damaged area. The number 
of damaged areas between $5000 \mathrm{~m}^{2}$ and $10,000 \mathrm{~m}^{2}$ was 133 , the second most abundant size category. Therefore, approximately $87 \%$ of the damage was analyzed to be relatively small; approximately $13 \%$ of the damaged areas was found to be damaged over $50,000 \mathrm{~m}^{2}$.

\subsection{Field Surveys}

\subsubsection{Status of Damaged Areas by Region}

As per the field surveys conducted over 2 years, 288 areas were categorized as actually damaged areas (Table 5). Of the 399 damaged areas derived through remote sensing, approximately $72 \%$ of the areas were found to be actual damaged areas; it is judged that the methodology used in this study detected the damaged areas with good accuracy. As per the field surveys, approximately $90 \%$ of the damaged areas were found to have an area of $50,000 \mathrm{~m}^{2}$ or less-almost the same as the ratio obtained through remote sensing. Contrastingly, in the case of distribution by region, in the analysis using remote sensing, the number of damaged areas in Gyeonggi-do and Gangwon-do was similar, but 35 areas of Gangwon-do were excluded from the field survey. In Gangwon-do, the forest area accounted for more than $80 \%$ of land cover; Rocky Mountains, quarries, and talus areas were widely distributed. In this study, natural environmental damage was defined as a change into a barren area; the damaged areas detected through remote sensing were often classified into the above three topographies. Rocky mountains and quarries were excluded as natural ecosystems that require management. The term talus has been used to define the landform of cliffs containing conical-pile form rock fragments and was excluded as a natural phenomenon [48] (Figure 6). Most of the other excluded areas are currently under development or have already been completed and post-processed. This was considered to be an error due to differences between the land-cover map construction time and the current land status.

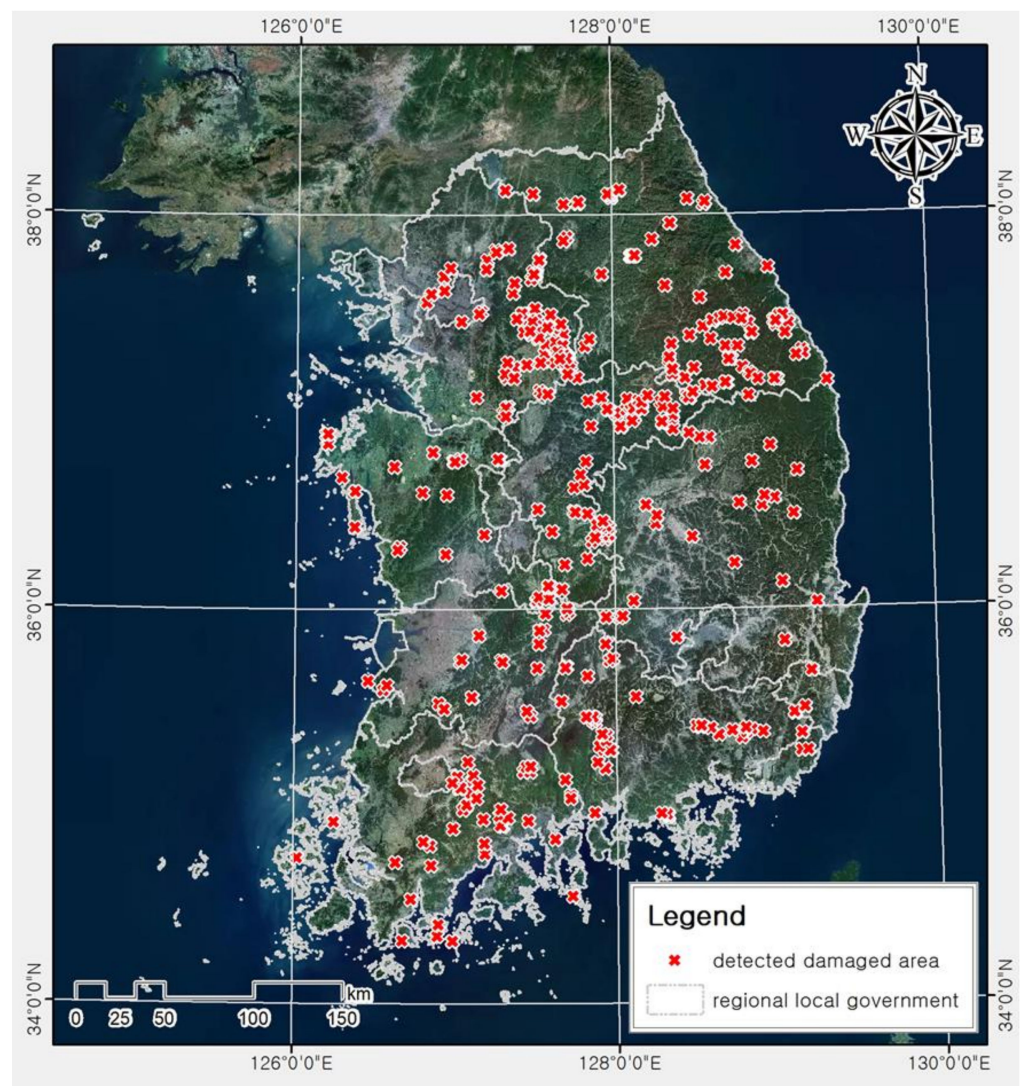

Figure 5. Distribution status of damaged areas in South Korea derived through remote sensing. 


\subsubsection{Status of Damaged Areas by Causes and Types}

Through the field surveys, $62 \%$ of ecological damage occurred in the forest ecosystem, $14 \%$ was found in barren areas, and the rest were grassland and agricultural ecosystems, etc. It is considered that $63 \%$ of Korea's land cover is forests and considered to be due to a result of continuous development projects and illegal damage to forest lands. Contrastingly, the land-cover type with the least damage was urban areas. As with the results of the remote sensing analysis, it appears that there is slight damage in the areas where urbanization has already progressed (see Figure A1).

According to the results of the investigation into the cause of the damage, approximately $97 \%$ of the damage was caused by anthropogenic factors; there were almost eight cases of damage caused by natural causes (Figure 7b). In Gangwon-do, which is expected to have a large amount of forest damage, most areas that appeared to be natural talus areas, quarries, etc., rather than actually damaged areas, were excluded from the list of damaged areas.

In the case of damage type, approximately $66 \%$ of damage was soil erosion. Soil erosion is a damage type that is a problem worldwide and is mainly caused by forestry and agriculture (Figure 7d). The intensity of soil erosion occurrence is worsening owing to increases in population and human activities [49]. Through field surveys, most damage in Korea was identified as soil erosion due to deforestation and development targeting forest areas. There were 50 cases of soil degradation and ecosystem decline, which are other types of damage. This was therefore a relatively less important type of damage than soil erosion. These two types of damage are also caused by deforestation, salinization, habitat loss, and fragmentation caused by urbanization and human activities and can also partially occur in areas where soil erosion has occurred [50,51]. 
Table 5. Distribution status of damaged areas in South Korea derived through field surveys.

\begin{tabular}{|c|c|c|c|c|c|c|c|c|c|}
\hline Division & $\begin{array}{c}5000- \\
10,000 \\
\mathrm{~m} 2\end{array}$ & $\begin{array}{c}10,000- \\
50,000 \\
\mathrm{~m} 2\end{array}$ & $\begin{array}{c}50,000- \\
100,000 \\
\mathrm{~m} 2\end{array}$ & $\begin{array}{c}100,000- \\
150,000 \\
\text { m2 }\end{array}$ & $\begin{array}{c}150,000- \\
200,000 \\
\text { m2 }\end{array}$ & $\begin{array}{c}200,000- \\
250,000 \\
\mathrm{~m} 2\end{array}$ & $\begin{array}{c}250,000- \\
300,000 \\
\mathrm{~m} 2\end{array}$ & $\begin{array}{l}300,000 \\
\mathrm{~m} 2 \sim\end{array}$ & $\begin{array}{c}\text { Total } \\
\text { (Row) }\end{array}$ \\
\hline Seoul * & 1 & 1 & 1 & 0 & 0 & 0 & 0 & 0 & $3(1 \%)$ \\
\hline Busan * & 1 & 1 & 0 & 0 & 0 & 0 & 0 & 0 & $2(1 \%)$ \\
\hline Daegu * & 0 & 0 & 0 & 0 & 0 & 0 & 0 & 0 & $0(0 \%)$ \\
\hline Incheon * & 0 & 0 & 0 & 0 & 0 & 0 & 0 & 0 & $0(0 \%)$ \\
\hline Gwangju * & 0 & 0 & 0 & 0 & 0 & 0 & 0 & 0 & $0(0 \%)$ \\
\hline Daejeon * & 0 & 0 & 0 & 0 & 0 & 0 & 0 & 0 & $0(0 \%)$ \\
\hline Ulsan * & 1 & 1 & 0 & 0 & 0 & 0 & 0 & 0 & $2(1 \%)$ \\
\hline Sejong * & 0 & 0 & 0 & 0 & 0 & 0 & 0 & 0 & $0(0 \%)$ \\
\hline Gyeonggi-do & 20 & 52 & 4 & 0 & 1 & 1 & 3 & 0 & $\begin{array}{c}81 \\
(28 \%)\end{array}$ \\
\hline Gangwon-do & 18 & 27 & 1 & 0 & 0 & 1 & 0 & 0 & $\begin{array}{c}47 \\
(16 \%)\end{array}$ \\
\hline $\begin{array}{c}\text { Chungcheong } \\
\text { buk-do }\end{array}$ & 16 & 18 & 0 & 0 & 0 & 0 & 0 & 0 & $\begin{array}{c}34 \\
(12 \%) \\
\end{array}$ \\
\hline $\begin{array}{l}\text { Chungcheong } \\
\text { nam-do }\end{array}$ & 5 & 10 & 1 & 0 & 0 & 0 & 0 & 0 & $\begin{array}{c}16 \\
(5 \%) \\
\end{array}$ \\
\hline $\begin{array}{l}\text { Jeolla } \\
\text { buk-do }\end{array}$ & 9 & 7 & 0 & 0 & 0 & 1 & 1 & 0 & $\begin{array}{c}18 \\
(6 \%)\end{array}$ \\
\hline $\begin{array}{l}\text { Jeolla } \\
\text { nam-do }\end{array}$ & 13 & 16 & 5 & 0 & 0 & 0 & 0 & 0 & $\begin{array}{c}34 \\
(12 \%)\end{array}$ \\
\hline $\begin{array}{l}\text { Gyeongsang } \\
\text { buk-do }\end{array}$ & 7 & 17 & 2 & 2 & 0 & 0 & 0 & 0 & $\begin{array}{c}28 \\
(10 \%)\end{array}$ \\
\hline $\begin{array}{c}\text { Gyeongsang } \\
\text { nam-do }\end{array}$ & 7 & 12 & 0 & 2 & 0 & 0 & 0 & 2 & $\begin{array}{c}23 \\
(8 \%)\end{array}$ \\
\hline Total (column) & $\begin{array}{c}98 \\
(34 \%)\end{array}$ & $\begin{array}{c}162 \\
(56 \%)\end{array}$ & $\begin{array}{c}14 \\
(4 \%)\end{array}$ & $\begin{array}{c}4 \\
(1 \%)\end{array}$ & $\begin{array}{c}1 \\
(1 \%)\end{array}$ & $\begin{array}{c}3 \\
(1 \%)\end{array}$ & $\begin{array}{c}4 \\
(1 \%)\end{array}$ & $\begin{array}{c}2 \\
(1 \%)\end{array}$ & $\begin{array}{c}288 \\
(100 \%)\end{array}$ \\
\hline
\end{tabular}

*: metropolitan city in South Korea.
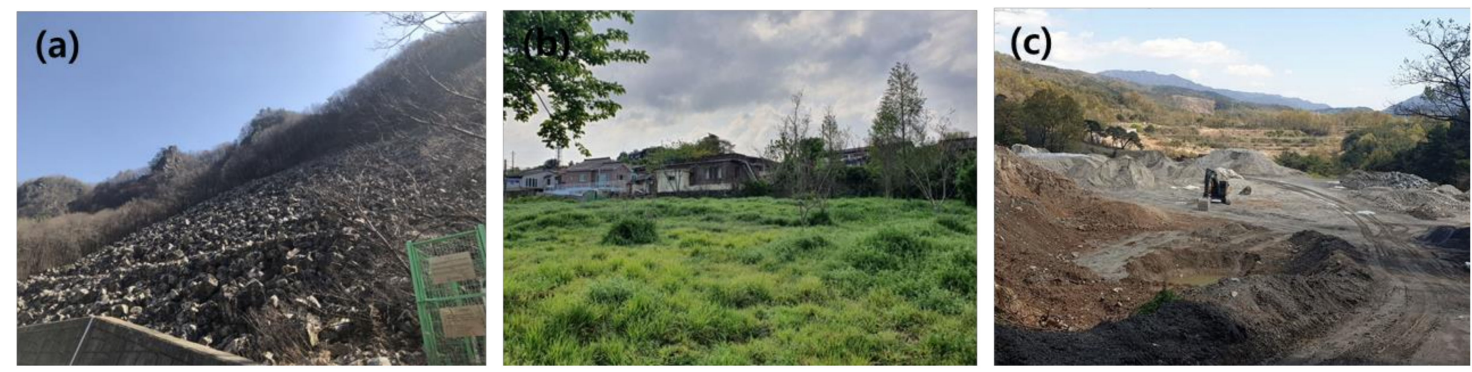

Figure 6. Examples of areas excluded from the damaged areas: (a) The area identified as talus in Gangwon-do; (b) the area where grassland was established in Gyeongsangnam-do; (c) the area where development is in progress in Gyeongsangnam-do. 

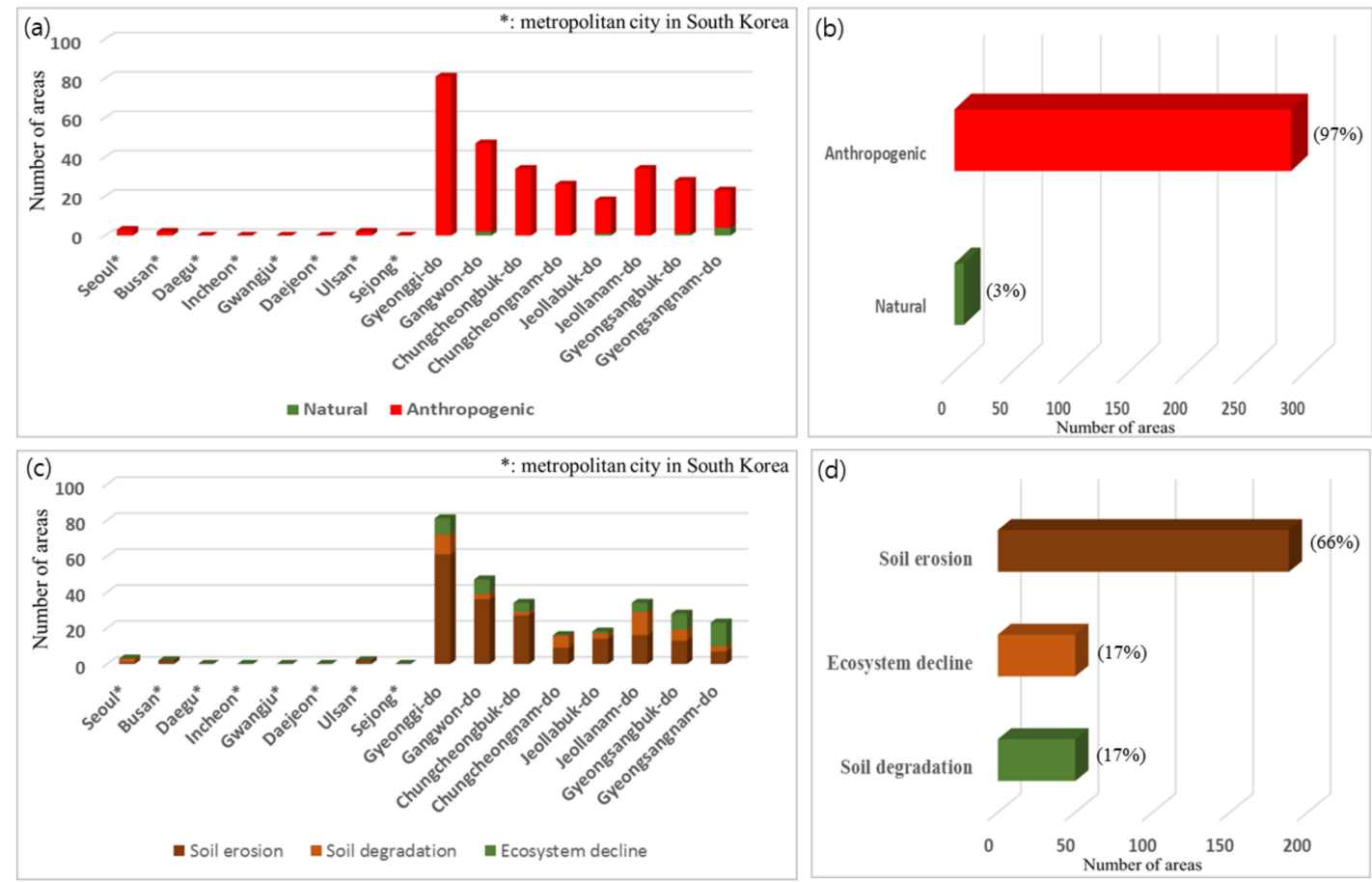

Figure 7. Distribution status of damaged areas in South Korea by cause and type: (a) Distribution of damaged areas by cause for each regional local government and; (b) total distribution of damaged areas by cause in South Korea; (c) Distribution of damaged areas by type for each regional local government and; (d) total distribution of damaged areas by type in South Korea.

In this study, the cause, type, and ecosystem of each damaged area were classified for the direction of restoration (Figure 8); however, when performing the actual restoration project, it is necessary to understand the complex type of damage to the damaged area and perform integrated and organic restoration considering the connection with surrounding ecosystems [7].
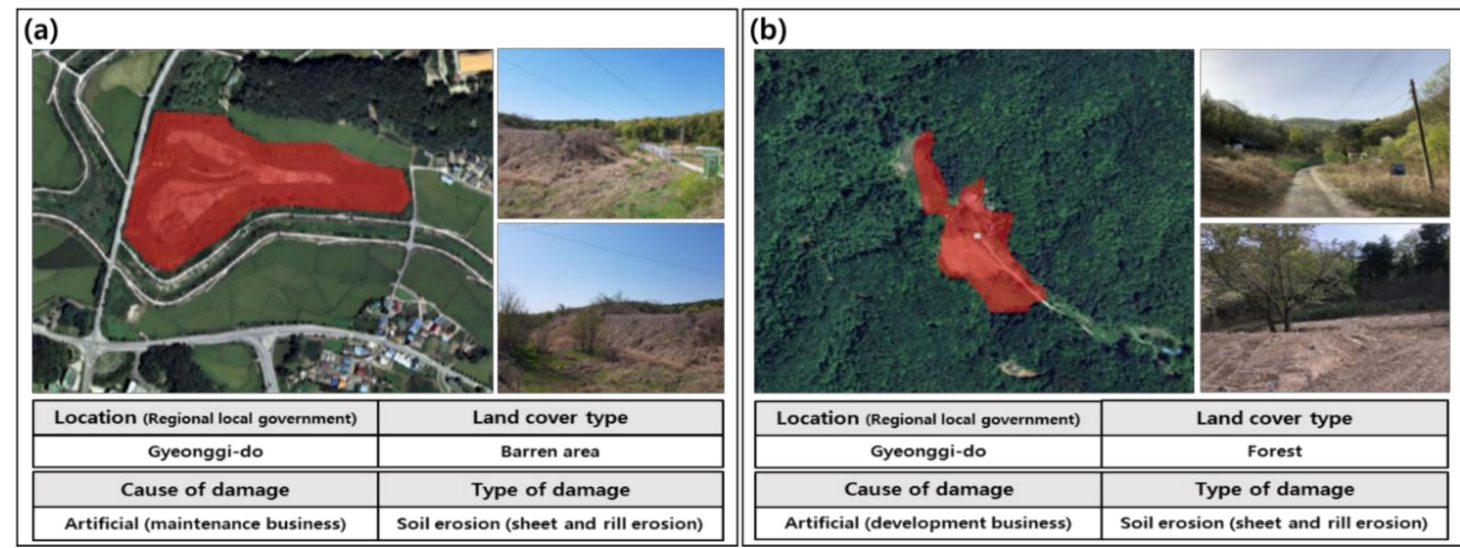

Figure 8. Examples of actual damage status derived through field surveys: (a) Damaged area where soil erosion occurred due to maintenance businesses in Gyeonggi-do; (b) Damaged area where soil erosion occurred due to development businesses in Gyeonggi-do.

\section{Discussion}

Damaged areas were derived through remote sensing using national standardized vector datasets and satellite images and verified through field surveys. Resultantly, more than $70 \%$ of the RS-derived damaged areas were found to be actual damage sites, suggesting the damage detection possibility of the methodology used here. Most of the damaged areas in South Korea were distributed in Gyeonggi-do 
and Gangwon-do; the areas were mostly less than 50,000 $\mathrm{m}^{2}$. Moreover, most of the damage incurred was soil erosion due to anthropogenic causes. Soil erosion mainly occurs in forest ecosystems and agricultural ecosystems. It was confirmed that $62 \%$ of the actual damage occurred in forest ecosystems; most were damaged by anthropogenic causes.

Most of the previous studies related to remote sensing for restoration have been carried out to detect physical changes using satellite imagery targeting the area where the damage may have occurred [14-18]. However, with simple detection of physical changes, it is difficult to determine the cause, type, and legality of the damage, and there is a limit inhibiting policy use. In this study, by applying national standardized vector datasets institutionally used for change detection worldwide, such as LULC maps and EIA maps, we confirmed that it is possible to judge whether the detected damage is illegal. In addition, information necessary for the restoration project was collected through field surveys that were not conducted in previous studies. Therefore, here, a database of the current status of the illegally damaged area distribution and damage type for each area was established. It is necessary to establish an effective restoration plan by related ministries and regional local governments using this database. It can also help promote the potential to meet the environmental conservation and economic development of the environmental offsets policy by providing sites for developing/refining/informing restoration methods [20,22]. Additionally, based on these results, additional policy proposals are needed to prevent the ecological damage caused by development and illegal human activities targeting forests.

However, legal basis and criteria for ecologically damaged areas and the degree of dataset and thematic map construction may differ by country. Even if other countries' data is different from the data used here, it is judged that if the spatial data related to the zoning, protected area, and development activities established at the national level are used, it will be possible to derive damage in each country. The land-cover map used here has a high resolution, but the constructed time is different from the present. Thus, there are limitations in which the damaged areas are different from the current land cover; no additional damaged areas could be derived. To improve the accuracy of future research, it is necessary to utilize the latest high-resolution land-cover maps and additional legal thematic maps related to the damage of the ecological environment at the national level.

\section{Conclusions}

In this study, we applied two-step methodology to detect ecologically damaged areas and monitor them in South Korea for the period 2008-2017 using both remote sensing and field surveys. We used national standardized vector datasets and Google Earth data to analyze the illegally changed areas and then conducted field surveys for 2 years to verify the derived results and determine the type of damage. As a result, 288 damaged areas of the 399 damaged derived through remote sensing were found to be actual damaged areas. It means that our remote sensing approach using combination of imagery related with environmental change proved to be an effective method to detect illegally changed areas with $72 \%$ accuracy. Furthermore, our data shows that $62 \%$ of ecological damage occurred in the forest ecosystem and $66 \%$ of damage was soil erosion. Therefore, when establishing a restoration plan in South Korea in the future, it is necessary to expand the budget for ministries related to forest and to recruit soil erosion experts. Finally, we suggest that the proposed approach is a viable to tool to detect ecologically damaged areas but flexible application is required according to the situation of each damaged area, such as changing the combination of maps to be used.

Author Contributions: This paper represents a result of collaborative teamwork. Conceptualization, K.L. and S.W.J.; data curation, H.C.S., J.-Y.S. and J.H.K.; investigation, K.L. and J.-Y.S.; methodology, K.L. and Y.Y.; visualization, Y.Y., Y.K. and J.H.K.; writing-original draft, K.L.; filed survey, K.L., H.C.S., J.-Y.S., Y.Y., Y.K., J.H.K. and S.W.J.; project administration, supervision, and funding acquisition, S.W.J. All authors have read and agreed to the published version of the manuscript.

Funding: This research was supported by the Korea Environment Industry and Technology Institute (KEITI) grant (No. 2018000210006), funded by the Ministry of the Environment (MOE). 
Conflicts of Interest: The authors declare no conflict of interest.

\section{Appendix A}

Table A1. Status of urban development projects in South Korea (2008-2017).

\begin{tabular}{|c|c|c|c|c|c|c|}
\hline \multirow{2}{*}{ Division } & \multicolumn{2}{|c|}{ Total } & \multicolumn{2}{|c|}{ Ongoing } & \multicolumn{2}{|c|}{ Finished } \\
\hline & Number & $\begin{array}{c}\text { Area } \\
(1000 \mathrm{~m} 2)\end{array}$ & Number & $\begin{array}{c}\text { Area } \\
(1000 \mathrm{~m} 2)\end{array}$ & Number & $\begin{array}{c}\text { Area } \\
(1000 \mathrm{~m} 2)\end{array}$ \\
\hline Seoul * & 10 & 9858 & 10 & 9858 & - & - \\
\hline Busan * & 10 & 1557 & 2 & 1303 & 8 & 254 \\
\hline Daegu * & 13 & 859 & 9 & 709 & 4 & 150 \\
\hline Incheon * & 29 & 10,628 & 19 & 7305 & 10 & 3323 \\
\hline Gwangju * & 13 & 2282 & 8 & 2085 & 5 & 197 \\
\hline Daejeon * & 14 & 4412 & 8 & 949 & 6 & 3463 \\
\hline Ulsan * & 11 & 4379 & 9 & 4043 & 2 & 336 \\
\hline Sejong * & 1 & 232 & 1 & 232 & - & - \\
\hline Gyeonggi-do & 138 & 47,278 & 104 & 38,460 & 34 & 8818 \\
\hline Gangwon-do & 17 & 2283 & 10 & 1730 & 7 & 553 \\
\hline Chungcheongbuk-do & 14 & 3296 & 12 & 2998 & 2 & 298 \\
\hline Chungcheongnam-do & 54 & 13,634 & 25 & 6165 & 29 & 7469 \\
\hline Jeollabuk-do & 10 & 8670 & 5 & 5038 & 5 & 3632 \\
\hline Jeollanam-do & 20 & 7952 & 12 & 6456 & 8 & 1496 \\
\hline Gyeongsangbuk-do & 40 & 10,668 & 24 & 8634 & 16 & 2034 \\
\hline Gyeongsangnam-do & 51 & 16,424 & 26 & 11,042 & 25 & 5382 \\
\hline total (column) & 445 & 144,412 & 284 & 107,007 & 161 & 37,405 \\
\hline
\end{tabular}

\section{Appendix B}
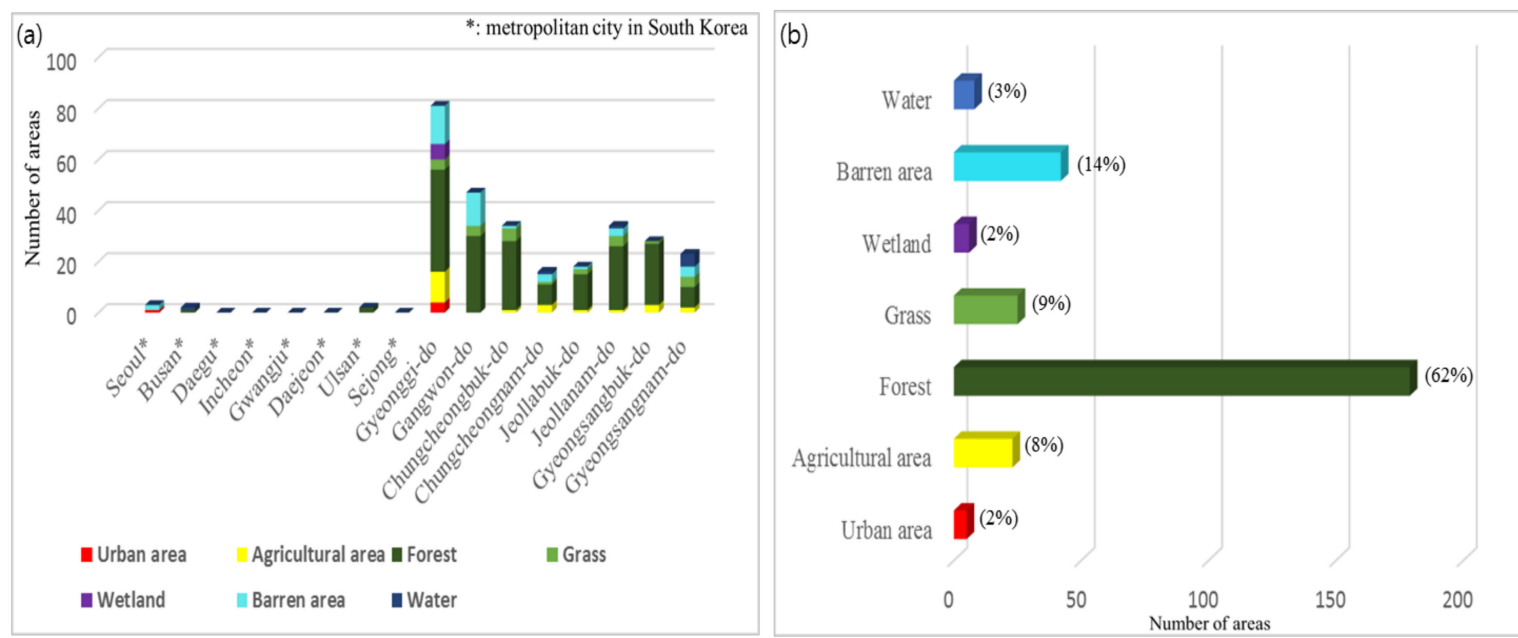

Figure A1. Distribution status of damaged areas in South Korea by ecosystem. (a) Distribution of damaged areas by ecosystem for each regional local government and (b) total distribution of damaged areas by ecosystem in South Korea. 


\section{References}

1. Fereidoun, H.; Nourddin, M.S.; Rreza, N.A.; Mohsen, A.; Ahmad, R.; Pouria, H. The effect of long-term exposure to particulate pollution on the lung function of Teheranian and Zanjanian students. Pak. J. Physiol. 2007, 3 .

2. Reed, M.S.; Dougill, A.J.; Taylor, M.J. Integrating local and scientific knowledge for adaptation to land degradation: Kalahari rangeland management options. Land Degrad. Dev. 2007, 18, 249-268. [CrossRef]

3. Costanza, R.; De Groot, R.; Sutton, P.; Ploeg, S.; Anderson, S.; Kubiszewski, I.; Farber, S.; Turner, R.K. Changes in the global value of ecosystem services. Glob. Environ. Chang. 2014, 26, 152-158. [CrossRef]

4. Hobbs, R.J.; Cramer, V.A. Restoration ecology: Interventionist approaches for restoring and maintaining ecosystem function in the face of rapid environmental change. Annu. Rev. Environ. Resour. 2008, 33, 39-61. [CrossRef]

5. Aradóttir, Á.L.; Petursdottir, T.; Halldorsson, G.; Svavarsdottir, K.; Arnalds, O. Drivers of ecological restoration: Lessons from a century of restoration in Iceland. Ecol. Soc. 2013, 18, 14. [CrossRef]

6. Luuppala, L. Ecological Restoration: Conceptual Analysis and Ethical Implications; HELDA-University of Helsinki: Helsinki, Finland, 2015.

7. Ministry of Environment. Research for the Systematic Restoration of the Damaged Natural Environment; Republic of Korea, Ministry of Environment: Sejong City, Korea, 2011. (In Korean)

8. Suding, K.N. Toward an era of restoration in ecology: Successes, failures, and opportunities ahead. Annu. Rev. Ecol. Evol. Syst. 2011, 42, 465-487. [CrossRef]

9. Zhang, D.; Jia, Q.; Wang, P.; Zhang, J.; Hou, X.; Li, X.; Li, W. Analysis of spatial variability in factors contributing to vegetation restoration in Yan'an, China. Ecol. Indic. 2020, 113, 1062-1078. [CrossRef]

10. DeLuca, T.H.; Aplet, G.H.; Wilmer, B.; Burchfield, J. The unknown trajectory of forest restoration: A call for ecosystem monitoring. J. For. 2010, 108, 288-295.

11. Hooper, M.J.; Glomb, S.J.; Harper, D.D.; Hoelzle, T.B.; McIntosh, L.M.; Mulligan, D.R. Integrated risk and recovery monitoring of ecosystem restorations on contaminated sites. Integr. Environ. Assess. Manag. 2016, 12, 284-295. [CrossRef]

12. Nagendra, H.; Lucas, R.; Honrado, J.P.; Jongman, R.H.; Tarantino, C.; Adamo, M.; Mairota, P. Remote sensing for conservation monitoring: Assessing protected areas, habitat extent, habitat condition, species diversity, and threats. Ecol. Indic. 2013, 33, 45-59. [CrossRef]

13. Lu, D.; Mausel, P.; Brondizio, E.; Moran, E. Change detection techniques. Int. J. Remote Sens. 2004, 25, 2365-2401. [CrossRef]

14. Bellón, B.; Blanco, J.; Vos, A.D.; Roque, F.D.O.; Pays, O.; Renaud, P.C. Integrated Landscape Change Analysis of Protected Areas and their Surrounding Landscapes: Application in the Brazilian Cerrado. Remote Sens. 2020, 12, 1413. [CrossRef]

15. Kintz, D.B.; Young, K.R.; Crews-Meyer, K.A. Implications of land use/land cover change in the buffer zone of a national park in the tropical Andes. Environ. Manag. 2006, 38, 238-252. [CrossRef] [PubMed]

16. Reif, M.K.; Theel, H.J. Remote sensing for restoration ecology: Application for restoring degraded, damaged, transformed, or destroyed ecosystems. Integr. Environ. Assess. Manag. 2017, 13, 614-630. [CrossRef]

17. Scharsich, V.; Mtata, K.; Hauhs, M.; Lange, H.; Bogner, C. Analysing land cover and land use change in the Matobo National Park and surroundings in Zimbabwe. Remote Sens. Environ. 2017, 194, 278-286. [CrossRef]

18. Szantoi, Z.; Brink, A.; Buchanan, G.; Bastin, L.; Lupi, A.; Simonetti, D.; Mayaux, P.; Peedell, S.; Davy, J. A simple remote sensing-based information system for monitoring sites of conservation importance. Remote Sens. Ecol. Conserv. 2016, 2, 16-24. [CrossRef]

19. Willis, K.S. Remote sensing change detection for ecological monitoring in United States protected areas. Biol. Conserv. 2015, 182, 233-242. [CrossRef]

20. Bull, J.W.; Suttle, K.B.; Gordon, A.; Singh, N.J.; Milner-Gulland, E.J. Biodiversity offsets in theory and practice. Oryx 2013, 47, 369-380. [CrossRef]

21. Martin, N.; Evans, M.; Rice, J.; Lodhia, S.; Gibbons, P. Using offsets to mitigate environmental impacts of major projects: A stakeholder analysis. J. Environ. Manag. 2016, 179, 58-65. [CrossRef]

22. CSBI (Cross Sector Biodiversity Initiative). A Cross-Sector Guide for Implementing the Mitigation Hierarchy; Biodiversity Consultancy: Cambridge, UK, 2015. 
23. Rhodes, C.J.; Henrys, P.; Siriwardena, G.M.; Whittingham, M.J.; Norton, L.R. The relative value of field survey and remote sensing for biodiversity assessment. Methods Ecol. Evol. 2015, 6, 772-781. [CrossRef]

24. Yoo, C.; Im, J.; Cho, D.; Yokoya, N.; Xia, J.; Bechtel, B. Estimation of All-Weather 1 km MODIS Land Surface Temperature for Humid Summer Days. Remote Sens. 2020, 12, 1398. [CrossRef]

25. Environmental Geographic Information System. Available online: http://egis.me.go.kr (accessed on 13 August 2018).

26. Cohen, W.B.; Goward, S.N. Landsat's role in ecological applications of remote sensing. Bioscience 2004, 54, 535-545. [CrossRef]

27. Natoli, S.J. Zoning and the development of urban land use patterns. Econ. Geogr. 1971, 47, 171-184. [CrossRef]

28. Xia, Y.; Liu, D.; Liu, Y.; He, J.; Hong, X. Alternative zoning scenarios for regional sustainable land use controls in China: A knowledge-based multi objective optimisation model. Int. J. Environ. Res. Public Health 2014, 11, 8839-8866. [CrossRef] [PubMed]

29. Qian, Z. Without zoning: Urban development and land use controls in Houston. Cities 2010, $27,31-41$. [CrossRef]

30. Rossi-Hansberg, E. Optimal urban land use and zoning. Rev. Econ. Dyn. 2004, 7, 69-106. [CrossRef]

31. Xu, X.; Hou, L.; Lin, H.; Liu, W. Zoning of sustainable agricultural development in China. Agric. Syst. 2006, 87, 38-62. [CrossRef]

32. Ministry of Land, Infrastructure and Transport. National Land Planning and Utilization Act; Republic of Korea, Ministry of Land, Infrastructure and Transport: Sejong City, Korea, 2017.

33. National Spatial Data Information Portal. Available online: http://www.nsdi.go.kr/ (accessed on 14 August 2018).

34. Li, J.C. Environmental Impact Assessments in Developing Countries: An Opportunity for Greater Environmental Security; USAID, FESS: Washington, DC, USA, 2008.

35. El-Gafy, M.A.; Abdelrazig, Y.A.; Abdelhamid, T.S. Environmental impact assessment for transportation projects: Case study using remote-sensing technology, geographic information systems, and spatial modeling. J. Urban Plan. Dev. 2011, 137, 153-158. [CrossRef]

36. Moufaddal, W.M. Use of satellite imagery as environmental impact assessment tool: A case study from the NW Egyptian Red Sea coastal zone. Environ. Monit. Assess. 2005, 107, 427-452. [CrossRef]

37. Saroglu, E.; Bektas, F.; Dogru, A.O.; Ormeci, C.; Musaoglu, N.; Kaya, S. Environmental impact analyses of quarries located on the Asian side of Istanbul using remotely sensed data. In Proceedings of the XXII International Cartographic Conference (ICC), Corunna, Spain, 3-8 July 2011.

38. Ministry of Environment. Environmental Impact Assessment Act; Republic of Korea, Ministry of Environment: Sejong City, Korea, 2018.

39. Environmental Impact Assessment Support System. Available online: https://www.eiass.go.kr (accessed on 18 August 2018).

40. Pulighe, G.; Baiocchi, V.; Lupia, F. Horizontal accuracy assessment of very high resolution Google Earth images in the city of Rome, Italy. Int. J. Digit. Earth 2016, 9, 342-362. [CrossRef]

41. Eskandari, S.; Reza Jaafari, M.; Oliva, P.; Ghorbanzadeh, O.; Blaschke, T. Mapping Land Cover and Tree Canopy Cover in Zagros Forests of Iran: Application of Sentinel-2, Google Earth, and Field Data. Remote Sens. 2020, 12, 1912. [CrossRef]

42. Benker, S.C.; Langford, R.P.; Pavlis, T.L. Positional accuracy of the Google Earth terrain model derived from stratigraphic unconformities in the Big Bend region, Texas, USA. Geocarto Int. 2011, 26, 291-303. [CrossRef]

43. Ministry of Environment. Natural Environment Conservation Act; Republic of Korea, Ministry of Environment: Sejong City, Korea, 2018.

44. Ministry of Environment. Enforcement Decree of The Environmental Impact Assessment Act; Republic of Korea, Ministry of Environment: Sejong City, Korea, 2019.

45. Victoria Resources Online (VRO). Available online: http://vro.agriculture.vic.gov.au (accessed on 28 September 2018).

46. MOLIT Statistics System. Available online: http://stat.molit.go.kr (accessed on 5 April 2020).

47. Lee, C.J.; Yoo, N.J. A Study on Devris Flow Landslide Disasters and Restoration at Inje of Kangwon Province, Korea. J. Korean Soc. Hazard Mitig. 2009, 9, 99-106.

48. Zhang, Q.; Zhang, T.; Liu, X. Index system to evaluate the quarries ecological restoration. Sustainability 2018, 10, 619. [CrossRef] 
49. Pimentel, D.; Kounang, N. Ecology of soil erosion in ecosystems. Ecosystems 1998, 1, 416-426. [CrossRef]

50. Aulakh, M.S.; Sidhu, G.S. Soil degradation in India: Causes, major threats, and management options. In Proceedings of the MARCO symposium, Tsukuba, Japan, 26-28 August 2015; pp. 151-156.

51. Elmqvist, T.; Zipperer, W.G.; Guneralp, B. Urbanization, habitat loss, biodiversity decline: Solution pathways to break the cycle. In Routledge Handbook of Urbanization and Global Environmental Change; Seta, K., Solecki, W., Griffith, D., Corrie, A., Eds.; Routledge: London, UK, 2016; pp. 139-151.

Publisher's Note: MDPI stays neutral with regard to jurisdictional claims in published maps and institutional affiliations.

(C) 2020 by the authors. Licensee MDPI, Basel, Switzerland. This article is an open access article distributed under the terms and conditions of the Creative Commons Attribution (CC BY) license (http://creativecommons.org/licenses/by/4.0/). 